\title{
Kajian Filsafat Ilmu terhadap Pertambangan Batubara sebagai Upaya Meningkatkan Kesejahteraan Rakyat Indonesia
}

\author{
Irsan dan Meria Utama \\ Fakultas Hukum Universitas Sriwijaya \\ Jln. Raya Palembang Prabumulih, KM. 32 Inderalaya \\ Ogan Ilir Sumatera Selatan \\ irsan_cintafh@yahoo.com
}

\begin{abstract}
The major issue in this research is about the study on the general philosophy (ontology, epistemology and axiology) towards the use of natural resource of coal mining as an effort to improve the Indonesian people welfare. This is a normative research in which the research approach used the approach of philosophy of laws examining the legal values embedded in the law and regulation related to the use of natural resource of coal mining in Indonesia. the result of the research showed that first, in the study of ontology, coal mining has contributed to the national economy that is supposed to be run in harmony with the Article 33 sentence (3) and (4) of Constitution 1945. Reflection now is the governance of state is more dominant in its use; thus, it needs a new balance in the form of national management policy. Second, in the study of epistemology, there is a need to use the principle of sustainable development in the coal mining with people economic system and even distribution; and third, in axiology, there is a need of the direct and indirect use in improving the welfare of Indonesian people.
\end{abstract}

Keywords: Knowledge philosophy, coal mining, people welfare

Abstrak

Pokok permasalahan dalam penelitian ini adalah mengenai kajian filsafat ilmu (ontologi, epistimologi dan aksiologi) terhadap pemanfaatan sumber daya alam pertambangan batubara sebagai upaya meningkatkan kesejahteraan rakyat Indonesia. Penelitian ini merupakan penelitian normatif. Pendekatan penelitian yang digunakan adalah pendekatan filsafat ilmu hukum yaitu meneliti nilai-nilai hukum yang terkandung di balik peraturan perundang-undangan yang terkait dengan pemanfaatan sumber daya alam pertambangan batubara di Indonesia. Hasil penelitian menunjukkan bahwa pertama, pada kajian ontologi pertambangan batubara memberikan kontribusi terhadap perekonomian nasional yang seharusnya dijalankan secara selaras sesuai Pasal 33 ayat (3) dan (4) UUD 1945. Refleksi saat ini adalah penguasaan oleh negara lebih mendominasi pemanfaatannya, sehingga perlu penyeimbang baru berupa kebijakan pengelolaan nasional. Kedua, pada kajian epistimologi perlu menggunakan prinsip pembangunan berkelanjutan pada pertambangan batubara dengan sistem ekonomi kerakyatan dan pemerataan. Ketiga, pada kajian aksiologi perlu adanya pemanfaatan langsung dan tidak langsung dalam meningkatkan kesejahteraan rakyat Indonesia.

Kata-kata Kunci: Filsafat ilmu, pertambangan batubara, kesejahteraan rakyat 


\section{Pendahuluan}

Letak geografis yang strategis menunjukkan betapa kaya Indonesia akan sumber daya alam dengan segala flora, fauna dan potensi hidrografis dan deposit sumber alamnya yang melimpah. Sumber daya alam Indonesia berasal dari pertanian, kehutanan, kelautan dan perikanan, perternakan, perkebunan serta pertambangan dan energi.

Pertambangan dan energi diharapkan menjadi primadona sumber penerimaan devisa. Dua komoditi tambang tersebut kuantitasnya sangat mempengaruhi kondisi perekonomian Indonesia, sehingga sering digunakan sebagai asumsi dasar dalam perencanaan Anggaran Pendapatan dan Belanja Negara (APBN). Energi listrik sebagian besar masih diproduksi PT Perusahaan Listrik Negara (PLN), sedangkan sisanya oleh perusahaan-perusahaan yang dikelola Pemerintah Daerah, koperasi, atau perusahaan swasta lainnya. Pemerintah juga menggali sumber-sumber energi alternatif untuk mengurangi ketergantungan kepada BBM. Sumber energi aternatif yang dimiliki dalam jumlah besar adalah gas, batubara, tenaga hidro, panas bumi, dan tenaga surya. (lihat tabel 1. cadangan energi fosil dan energi alternatif) Energi alternatif yang saat ini tengah digarap pemerintah adalah energi berbasis nabati atau biofuel dengan bahan dasar tanaman perkebunan seperti kelapa sawit, tebu, singkong, dan jarak. ${ }^{1}$

Akhmad Fauzi mengungkapkan bahwa salah satu potensi yang dimiliki bangsa Indonesia yang sangat besar nilainya dibandingkan dengan bangsa-bangsa lain di dunia adalah sumberdaya alam (renewable dan nonrenewable). Dengan demikian, bangsa Indonesia perlu berbangga sekaligus bersyukur kepada Tuhan Yang Maha Esa atas limpahan karunia-Nya itu sehingga kehidupan bangsa Indonesia dapat berlangsung hingga saat ini. Oleh karena itu, hilangnya atau berkurangnya ketersediaan sumberdaya ini akan berdampak besar bagi kelangsungan hidup bangsa Indonesia pada khususnya dan umat manusia di muka bumi pada umumnya. ${ }^{2}$

\footnotetext{
${ }^{1}$ http://www.indonesia.go.id/in/potensi-daerah/sumber-daya-alam, diakses 15 Desember 2015.

2Imadi Nahib, "Pengelolaan sumberdaya tidak pulih berbasis ekonomi sumberdaya (Studi Kasus: tambang Minyal Blok Cepu)", Jurnal Ilmiah Geomatifka, Vol. 12 No. 1 Agustus 2006, hlm. 2.
} 
Tabel 1. Cadangan Energi Fosil dan Energi Terbarukan

A. Energi Fosil

\begin{tabular}{|c|c|c|c|c|}
\hline Minyak Bumi & $\begin{array}{c}86,9 \\
\text { milyar bbl }\end{array}$ & 5 milyar bbl & 500 juta bbl & 10 tahun \\
\hline Gas Bumi & 385 TSCF & 90 TSCF & 2,9 TSCF & 30 tahun \\
\hline Batubara & $50 \begin{array}{c}\text { milyar } \\
\text { Ton }\end{array}$ & 5 milyar Ton & 100 juta Ton & 50 tahun \\
\hline
\end{tabular}

B. Energi Terbarukan

\begin{tabular}{|l|c|c|}
\hline & Potensi & Kapasitas Terpasang \\
\hline Tenaga Air & $75.67 \mathrm{GW}$ & $4200 \mathrm{MW}$ \\
\hline Panas Bumi & $27 \mathrm{GW}$ & $\mathbf{8 0 7} \mathrm{MW}$ \\
\hline Mini/ Micro hydro & $\mathbf{7 1 2} \mathbf{~ M W}$ & $206 \mathrm{MW}$ \\
\hline Biomassa & $49.81 \mathrm{GW}$ & $\mathbf{3 0 2 . 4} \mathbf{M W}$ \\
\hline Tenaga Surya & $4.8 \mathrm{kWh} / \mathbf{m}^{2} / \mathbf{h a r i}$ & $\mathbf{M W}$ \\
\hline Tenaga Angin & $3-6 \mathrm{~m} /$ detik & $\mathbf{0 . 6} \mathbf{M W}$ \\
\hline
\end{tabular}

Sumber: Kebijakan Energi Nasional-Direktorat Jenderal Listrik dan Pemanfaatan Energi (KENDJLPE), 2014.

Sumber daya alam bangsa Indonesia yang begitu besar, tetapi masyarakatnya harus tetap menjadi miskin ${ }^{3}$ demi memperkaya bangsa asing yang bebas beroperasi dinegara ini. Sadar atau tidak sadar kepentingan pihak asing terus menerus melancarkan metode penjajahan baru atau neo-imperialisme. Sebagi contoh, hingga 70 tahun Indonesia merdeka 75 persen tambang batubaraIndonesia dikuasai korporasi asing. ${ }^{4}$ Hasilnya dikirim dan dinikmati oleh negara-negara maju, sementara Indonesia sebagai pemilik Sumber Daya Alam (SDA) hanya mendapatkan bagian yang sedikit.

Batubara merupakan salah satu komoditas energi penting di Indonesia. Penambangan telah berlangsung sejak masa kolonial Belanda. Sejarah penambangan batubara dapat dibagi berdasarkan pulau lokasi penambangan. Penambangan batubara oleh Belanda dilakukan pertama kali di Pulau Kalimantan dan Pulau Sumatera yang saat ini menjadi produsen utama batubara di Indonesia.

Batubara di Indonesia dikenal sebagai batubara eosen dan endapan batubara miosen. Endapan batubara eosen merupakan bagian dari endapan paleogen dan

${ }^{3}$ Berdasarkan data ranking 182 negara, Indonesia berada di urutan ke 122 dengan PDB per kapita US\$4.380 atau Rp. 39.400.000 per tahun. http://bisnis.news.viva.co.id/news/read/178888-negara-terkaya---termiskin-dimana-indonesia-, diakses 15 Desember 2015.

${ }^{4}$ http://www.metrosiantar.com/2013/08/01/73888/mayoritas-sumber-energi-dikuasai-asing/, diakses 15 Desember 2015. 
terbentuk di sepanjang tepian paparan sunda, di sebelah barat Sulawesi, Kalimantan Bagian Timur, Laut Jawa, hingga Sumatera. Penambangan batubara di masa sekarang di Indonesia sebagian besar dilakukan pada batubara miosen. Distribusi batubara eosen dan miosen di Indonesia hampir merata di Pulau Sumtera dan Kalimantan, mengikuti sebaran cekungan-cekungan pembaga batubara ekonomis (lihat Gambar 1).

Gambar 1. Sebaran cekungan batubara di Indonesia

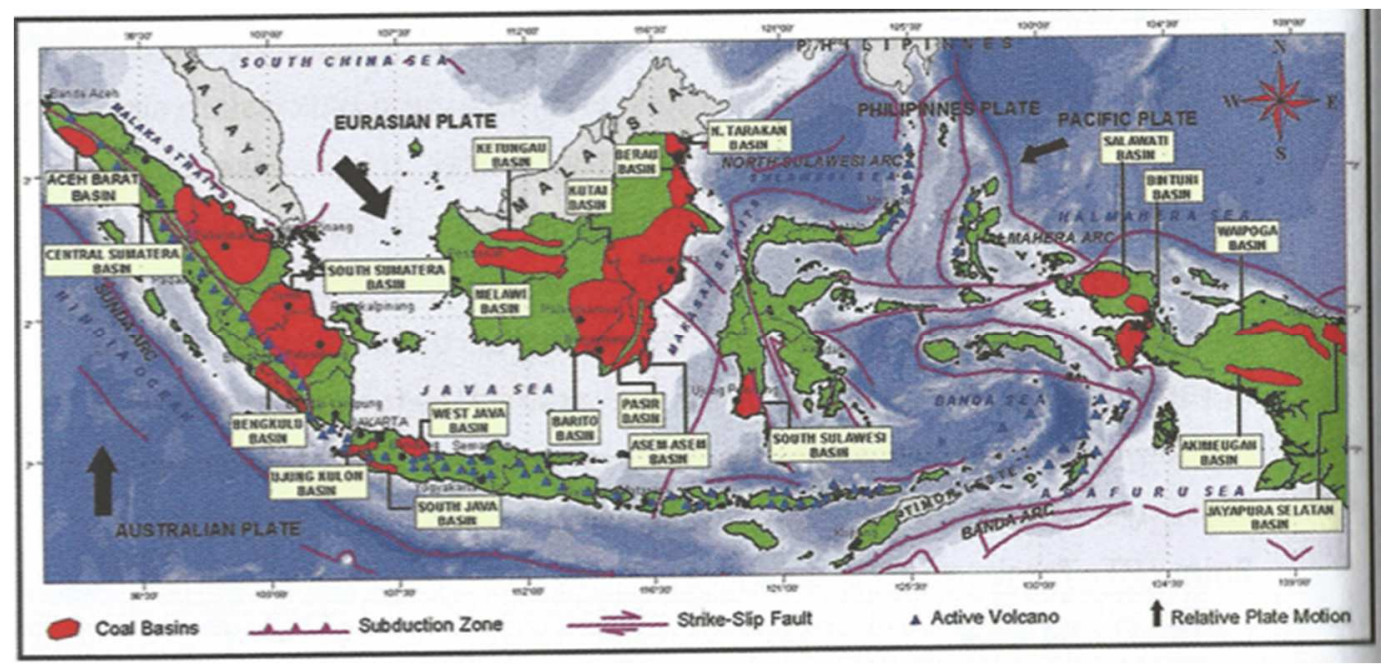

Sumber: Badan Geologi, 2011.

Adapun data produksi, ekspor dan pemakaian domestik batubara Indonesia dari tahun 2008 sampai dengan 2013 adalah sebagai berikut (lihat Tabel 2):

Tabel. 2. Produksi, ekspor dan pemakaian domestik batubara Indonesia Tahun 2008-2013 dalam jutaan ton

\begin{tabular}{lcccccc}
\hline Penggunaan & $\mathbf{2 0 0 8}$ & $\mathbf{2 0 0 9}$ & $\mathbf{2 0 1 0}$ & $\mathbf{2 0 1 1}$ & $\mathbf{2 0 1 2}$ & $\mathbf{2 0 1 3}$ \\
\hline Produksi & 240 & 254 & 275 & 353 & 386 & 421 \\
Ekspor & 181 & 198 & 208 & 273 & 304 & 349 \\
Pemakaian domestik & 53 & 56 & 67 & 80 & 82 & 72 \\
\hline
\end{tabular}

Sumber: Direktorat mineral dan batubara Kementrian Energi dan Sumber Daya Mineral, 2013.

Secara umum, penggunaan batubara di Indonesia adalah untuk ekspor dan domestik. Batubara di Indonesia dipakai untuk beberapa sasaran utama, seperti listrik dan industri semen. Sejak jaman kolonial, lebih dari $50 \%$ produksi batubara telah diekspor ke luar Indonesia. Menurut ANZ, ekspor batubara Indonesia paling besar terhadap jumlah produksi yang dimiliki (Gambar 2). 
Gambar 2. Perbandingan Tingkat Produksi dan Ekspor Batubara di beberapa Negara Penghasil Batubara Dunia
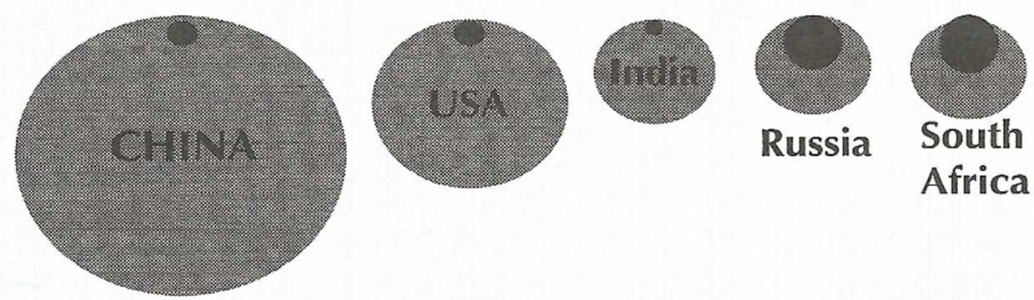

Africa

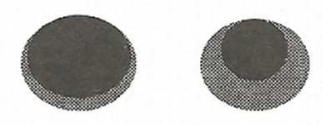

Indonesia Australia

Production

Exports

Sumber: Wood Machencie, Coal Supply Services, ANZ, 2011.

Dari data di atas, tampak jelas terlihat bahwa cadangan batubara Indonesia yang tidak sebanding dengan cadangan batubara di negara lain di dunia $(0,6 \%)$, tetapi tingkat ekspor yang semakin tinggi setiap tahunnya. Hal ini harus menjadi perhatian secara serius, karena cadangan batubara di Indonesia sebagai penunjang energi dan ekonomi akan habis dalam waktu 100-an tahun kedepan.

Pemanfaatan tambang batubara dipergunakan untuk industri PLTU, mutalurgi, semen, tekstil, pupuk, dan pulp dalam negeri. ${ }^{5}$ Di sisi lain, negara mendapatkan manfaat langsung berupa pajak, penciptaan lapangan kerja dan program pengentasan kemiskinan berupa corporate social responsibility yang diberikan perusahaan kepada masyarakat. Tetapi masalah yang lain juga timbul diantaranya: terjadi kerusakan lingkungan, pelanggaran HAM dan keadilan sosial (social justice), ketimpangan dan kemiskinan (welfare and equality), serta masalah tenaga kerja (labor exploitation). ${ }^{6}$

Dari uraian di atas, harusnya sumberdaya alam tambang batubara sebagai tambang yang tidak dapat diperbaharui tersebut dikelola secara bijaksana agar dapat dimanfaatkan secara berdaya guna, berhasil guna, dan berkelanjutan demi kesejahteraan rakyat Indonesia, baik generasi sekarang maupun generasi yang akan datang bukan sebaliknya dikelola dan dimanfaatkan oleh pihak asing. Berdasarkan penjelasan diatas, peneliti akan membahas bagaimana kajian filsafat ilmu terhadap pemanfaatan sumber daya alam pertambangan batubara sebagai upaya meningkatkan kesejahteraan rakyat Indonesia.

\footnotetext{
${ }^{5}$ Keputusan Menteri No. $1991 \mathrm{~K} / 30 / \mathrm{MEM} / 2011$ tentang penetapan kebutuhan dan persentase minimal penjualan batubara untuk kepentingan dalam negeri Tahun 2012.

${ }^{6}$ Dody Prayogo, "Corporate Social Responsibility, Social Justice dan Distributive welfare dalam Industri tambang dan migas di Indonesia”,Jurnal Galang,Volume 3 No. 3 Desember 2008.
} 
Filsafat ilmu merupakan kajian secara mendalam tentang dasar-dasar ilmu, sehingga Filsafat Ilmu menjawab pertanyaan ontologi, epistimologi, dan aksiologi dari suatu realitas. ${ }^{7}$ Pilihan pada pengkajian Filsafat Ilmu ini bertujuan untuk mendalami unsur-unsur pokok ilmu, sehingga secara menyeluruh dapat memahami sumber, hakikat dan tujuan ilmu.

\section{Rumusan Masalah}

Berdasarkan uraian pendahuluan, permasalahan yang diangkat dalam penelitian ini adalah bagaimana kajian filsafat ilmu (ontologi, epistimologi dan aksiologi) terhadap pemanfaatan sumber daya alam pertambangan batubara sebagai upaya meningkatkan kesejahteraan rakyat Indonesia?

\section{Tujuan Penelitian}

Penelitian ini bertujuan untuk menganalisis secara mendalam pemanfaatan sumber daya alam pertambangan batubara melalui kerangka filsafat ilmu (ontologi, epistimologi dan aksiologi) sebagai upaya meningkatkan kesejahteraan rakyat Indonesia.

\section{Metode Penelitian}

Penelitian ini tergolong jenis penelitian hukum normatif. Teknik pengumpulan data melalui studi kepustakaan (library research). Pendekatan yang digunakan adalah pendekatan filsafat ilmu hukum yaitu mengkaji nilai-nilai hukum di balik perundang-undangan yang terkait dengan pemanfaatan sumber daya alam pertambangan batubara di Indonesia. Data yang digunakan adalah data sekunder dengan menggunakan bahan hukum primer, sekunder dan tersier.

Setelah diperoleh data sekunder selanjutnya dilakukan inventarisir dan penyusunan secara sistematik kemudian diolah dan dianalisa secara deskriptif kualitatif, yakni pemaparan kembali dengan kalimat yang sistematis untuk dapat memberikan gambaran secara jelas atas permasalahan yang ada yang akhirnya dinyatakan dalam bentuk naratif.

${ }^{7}$ Amsal Bakhtiar, Filsafat Ilmu, PT RajaGrafindo Persada, Jakarta, 2005, hlm. 17-18. 


\section{Hasil Penelitian dan Pembahasan}

\section{Kajian Ontologi: Hakikat yang Dikaji}

Ontologi diartikan sebagai pengkajian mengenai hakikat realitas dari obyek yang ditelaah dalam membuahkan pengetahuan ${ }^{8}$ Kajian dalam tulisan ini mengenai 3 hal, pertama, filsafat ilmu, kedua, sumber daya alam pertambangan batubara, ketiga,upaya peningkatan kesejahteraan rakyat.

\section{Pengertian Filsafat Ilmu}

Filsafat berasal dari kata philos dan shopia. Philos artinya berpikir dan shopia artinya kebijaksanaan. Jadi filsafat adalah cinta kepada kebijaksanaa. Berpikir artinya mengolah data inderawi menjadi pengertian, atau proses mencari makna, dan kebijaksanaan artinya pengambilan keputusan yang memihak pihak yang lemah. Dengan demikian filsafat dapat diartikan berpikir mendalam tentang data indrawi dan pengambilan keputusan yang memihak kepada pihak yang lemah. ${ }^{9}$

Filsafat ilmu adalah penyelidikan filosofis tentang ciri-ciri pengetahuan ilmiah dan cara-cara untuk mempererolehnya. ${ }^{10}$ Konsep dasar filsafat ilmu adalah kedudukan, fokus, cakupan, tujuan dan fungsi serta kaitannya dengan implementasi kehidupan sehari-hari. Berikutnya dibahas pula tentang karakteristik filsafat, ilmu dan pendidikan serta jalinan fungsional antara ilmu, filsafat dan agama. Pembahasan filsafat ilmu juga mencakup sistematika, permasalahan, keragaman pendekatan dan paradigma (pola pikir) dalam pengkajian dan landasan pengembangan ilmu pengetahuan yang berdimensi ontologis, epistomologis dan aksiologis. ${ }^{11}$ Selanjutnya dikaji mengenai makna, implikasi dan implementasi filsafat ilmu sebagai landasan dalam rangka pengembangan keilmuan dan kependidikan dengan penggunaan alternatif metodologi penelitian, baik pendekatan kuantitatif dan kualitatif, maupun perpaduan kedua-duanya.

\footnotetext{
${ }^{8}$ Jujun S Suriarumantri, Filsafat Ilmu sebuab Pengantar Popular, Pustaka Sinar Harapan, Jakarta, 2013, hlm. 234.

${ }^{9}$ Darsono Prawiro Negoro, Filsafat Ilmu, Kajian tentang Pengetahuan yang Disusun secara Sistematis dan Sistemik dalam Membangun Ilmu Pengetahuan, Nusantara Consulting, Jakarta, 2011, hlm. 15.

${ }^{10}$ Tim Dosen Filsafat Ilmu Fakultas UGM, Filsafat Ilmu sebagai Dasar Pengembangan Ilmu Pengetahuan, Liberty, Yogyakarta, 2001, hlm. 44.

${ }^{11}$ https://sites.google.com/site/saefullahwiradipradja/lecture-materials, E. Saefullah Wiradipradja, Materi Filsafat Ilmu (Revisi) Program Studi Doktor Pascasarjana Universitas Padjadjaran, di akses 31 September 2015.
} 


\section{Sumber Daya Alam Pertambangan Batubara}

Pertambangan adalah sebagian atau seluruh tahapan kegiatan dalam rangka penelitian, pengelolaan dan pengusahaan batubara yang meliputi penyelidikan umum, eksplorasi, studi kelayakan, konstruksi, penambangan, pengolahan dan pemurnian, pengangkutan dan penjualan, serta kegiatan pascatambang. ${ }^{12}$

Pertambangan Batubara adalah pertambangan endapan karbon yang terdapat di dalam bumi, termasuk bitumen padat, gambut, dan batuan aspal.13Jumlah sumber daya dan cadangan batubara dapat diperhatikan berdasarkan pulau besar Indonesia (Gambar 3), Sumatera dan Kalimantan merupakan daerah penghasil batubara terbesar. Sumber daya batubara sumatera saat ini sekitar 53,68\% (85,03 Mton) dan cadangan batubara 52,61\% (14,79 Mton) dari potensi batubara nasional. ${ }^{14}$

Gambar 3. Cadangan Batubara Indonesia Berdasarkan Pulau Berdasarkan Cadangan Terbukti dan Cadangan Terkira

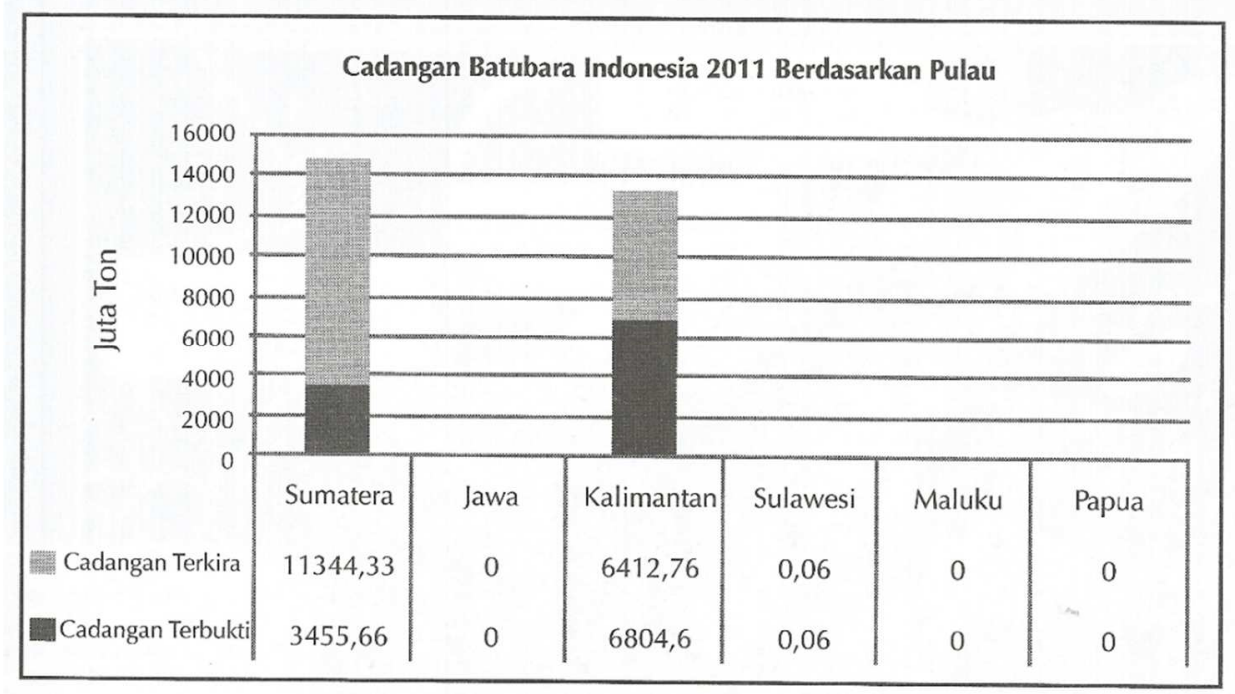

Sumber: Badan Geologi, 2011.

Sumber daya batubara di Indonesia berdasarkan data eksplorasi yang sudah diketahui dapat memenuhi penyediaan energi lebih dari 100 tahun kedepan. Berdasarkan data dari Direktorat pembinaan dan pegusahaan batubara sampai bulan Juli 2013, terdapat 3.903 perusahaan yang mendapatkan Izin Usaha Pertambangan (IUP) yang terdiri dari 2.537 IUP Eksplorasi dan 1.366 IUP Operasi Produksi. ${ }^{15}$

\footnotetext{
12 Pasal 1 ayat (1) Undang-Undang No.4 Tahun 2009 tentang Pertambangan Mineral dan Batubara.

13 Pasal 1 ayat (5) Undang-Undang No. 4 Tahun 2009 tentang Pertambangan Mineral dan Batubara.

14 Badan Geologi, Batubara di Indonesia, 2011.

15 Irwandi Arif, Batubara Indonesia, PT. Gramedia Pustaka, Jakarta, 2014, hlm. 63-64.
} 


\section{Upaya Peningkatan Kesejahteraan Rakyat.}

Tujuan dari pertambangan batubara dalam rangka peningkatan kesejahteraan rakyat sebagaimana ditegaskan dalam pembukaan UUD 1945 dan Pasal 33 (3) dan (4) UUD 1945. Dalam pembukaan UUD 1945 telah ditegaskan tujuan Negara Kesatuan Republik Indonesia. Ada empat tujuan Negara Kesatuan Republik Indonesia, yaitu: 1) Melindungi segenap bangsa Indonesia dan seluruh tumpah darah Indonesia; 2) Memajukan kesejahteraan umum; 3) Mencerdaskan kehidupan bangsa; 4) Ikut melaksanakan ketertiban dunia.

Salah satu tujuan utama dari keberadaan Negara Kesatuan Republik Indonesia adalah peningkatan kesejahteraan masyarakat. Untuk meningkatkan kesejahteraan masyarakat, maka segala sumber daya yang ada di Indonesia harus diupayakan dan dimanfaatkan secara optimal. Selanjutnya dalam Pasal 33 ayat (3) dan (4) UUD 1945, dinyatakan bahwa:

Ayat (3) "Bumi dan air dan kekayaan alam yang terkandung di dalamnya dikuasai oleh negara dan dipergunakan untuk sebesar-besar kemakmuran rakyat."

Ayat (4) "Perekonomian nasional diselenggarakan berdasar atas demokrasi ekonomi dengan prinsip kebersamaan, efisiensi berkeadilan, berkelanjutan, berwawasan lingkungan, kemandirian, serta dengan menjaga keseimbangan kemajuan dan kesatuan ekonomi nasional."

Pertambangan batubara memberikan konstribusi terhadap perekonomian nasional yang harusnya dijalankan secara selaras sesuai Pasal 33 ayat (3) dan (4) diatas. Namun dalam implementasinya, negara seringkali dihadapkan dalam kondisi dilematis antara pemanfaatan optimal dengan kerugian lingkungan dan sosial, termasuk menyeimbangkan pertumbuhan dan pemerataan. Refleksi saat ini adalah penguasaan oleh negara lebih mendominasi pemanfaatannya, sehingga perlu penyeimbang baru berupa kebijakan pengelolaan nasional.

\section{Kajian Epistemologi: Cara Mendapatkan Pengetahuan yang Benar}

Epistemologi membahas cara untuk mendapatkan pengetahuan, yang dalam kegiatan keilmuan disebut metode ilmiah. ${ }^{16}$ Metode Ilmiah adalah prosedur yang digunakan para ilmuwan meliputi berbagai tindakan pemikir, pola kerja, langkah-

${ }^{16}$ Jujun S Suriarumantri, Loc. Cit. 
langkah, dan teknik-teknik untuk memperoleh pengetahuan baru, mengoreksi atau mengembangkan ilmu (pengetahuan) yang telah ada secara sistematis. ${ }^{17}$

Alur berpikir dalam metode ilmiah ada dalam beberapa langkah yaitu: perumusan masalah, penyusunan kerangka berpikir, penyusan hipotesis, pengujian hipotesis dan penarikan kesimpulan. ${ }^{18}$

\section{Pertambangan Batubara dalam rangka Mewujudkan Pembangunan Berkelanjutan}

Batubara merupakan sumber daya untuk berkontribusi pada pertumbuhan ekonomi nasional dan pembanguan daerah secara berkelanjutan. Menurut Haris, dalam Fauzi ${ }^{19}$ melihat bahwa konsep keberlanjutan dapat diperinci menjadi 3 aspek pemahaman, yaitu:

a) Keberlanjutan ekonomi, yang diartikan sebagai pembangunan yang mampu menghasilkan barang dan jasa secara kontinu untuk memelihara keberlanjutan pemerintahan dan menghindari terjadinya ketidakseimbangan sektoral yang dapat merusak produksi pertanian dan industri.

b) Keberlanjutan lingkungan: Sistem yang berkelanjutan secara lingkungan harus mampu memelihara sumberdaya yang stabil, menghindari eksploitasi sumberdaya alam dan fungsi penyerapan lingkungan. Konsep ini juga menyangkut pemeliharaan keanekaragaman hayati, stabilitas ruang udara, dan fungsi ekosistem lainnya yang tidak termasuk kategori sumber-sumber ekonomi.

c) Keberlanjutan sosial: Keberlanjutan secara sosial diartikan sebagai sistem yang mampu mencapai kesetaraan, menyediakan layanan sosial termasuk kesehatan, pendidikan, gender, dan akuntabilitas politik.

Lebih jauh, hubungan antara lingkungan alam yang mendukung kehidupan manusia diawali pada kepentingan ekonomi, untuk kekayaan, konsumsi dan sektor produksi. Padahal ekosistem, lingkungan dan sumber daya alam yang ada harusnya dipertahankan karena mendukung kehidupan manusia. Perkembangan dewasa ini, karena tidak seimbangnya kepentingan ekonomi terhadap kepentingan kemanusian, terdapat upaya untuk mengembalikan kepentingan kemanusiaan (pendidikan, kelangsungan hidup anak, kesempatan yang sama, keadilan, dan tingkat harapan hidup) dan kelestarian lingkungan. Perubahan cara berpikir ini karena mengingat

${ }^{17}$ E. Saefullah Wiradipradja, Materi Filsafat Ilmu (Revisi), Loc. Cit

18 Ibid., hlm. 129.

19 Akhmad Fauzi, Ekonomi Sumber Daya Alam dan Lingkungan, Teori dan Aplikasi, PT. Gramedia Pustaka Utama, Jakarta. 2013, hlm. 37 
lingkungan yang sumber dayanya terbatas. Perubahan cara pikir ini dapat tergambarkan pada Gambar 4.

Gambar 4. Definition of Sustainable Development, bersumber dari U.S National

Research Concil, Policy Division, Board on Sustainable Development, Our Common Journey: A Transition Toward Sustainability (Washington, DC National

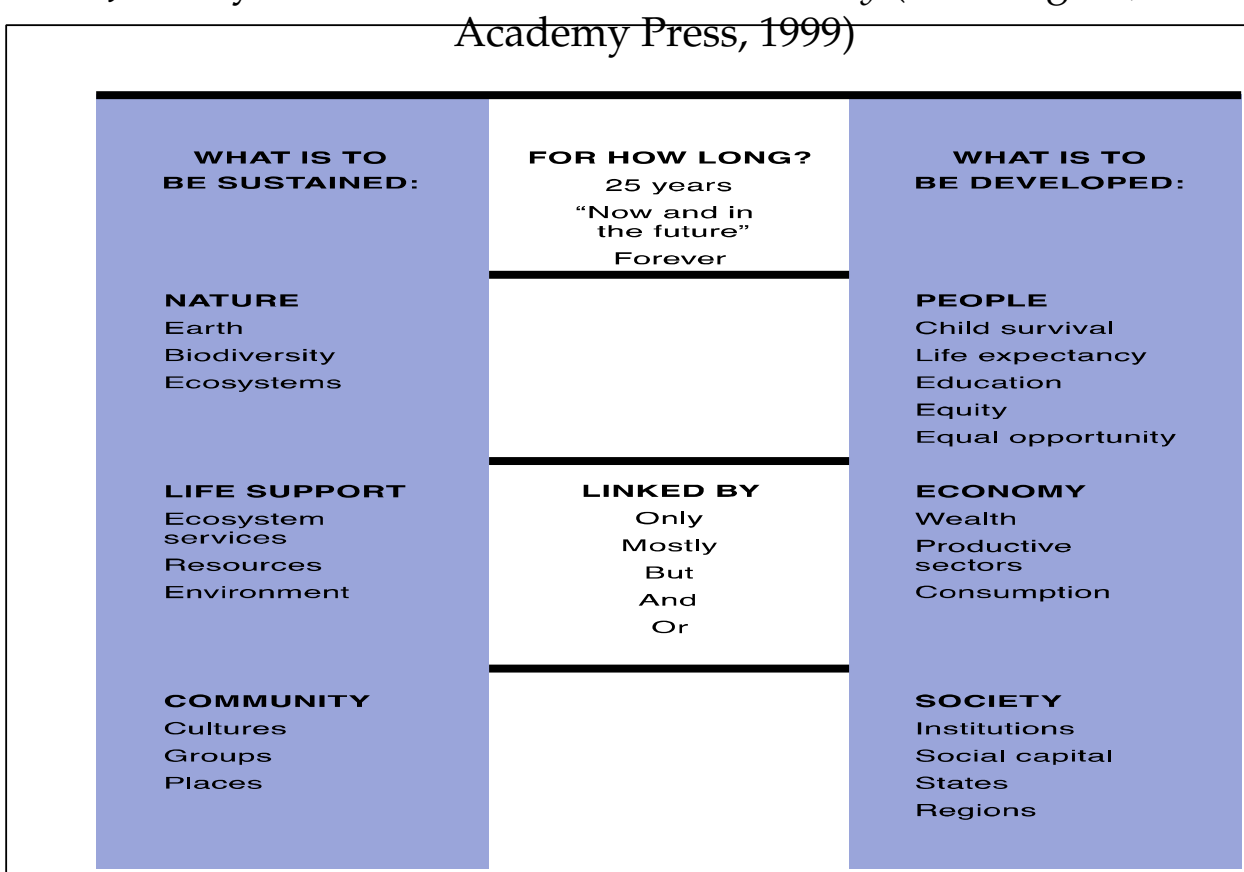

Sumber: Robert W Kates, et. al., "Enviroment: Science and Policy for Sustainable Development", Volume 47, number 3 Page 8-21, 2005.

Sutamihardja, menyatakan sasaran pembangunan berkelanjutan mencakup pada upaya untuk mewujudkan terjadinya: 20

1) Pemerataan manfaat hasil-hasil pembangunan antar generasi (intergenaration equity) yang berarti bahwa pemanfaatan sumberdaya alam untuk kepentingan pertumbuhan perlu memperhatikan batas-batas yang wajar dalam kendali ekosistem atau sistem lingkungan serta diarahkan pada sumberdaya alam yang replaceable dan menekankan serendah mungkin eksploitasi sumber daya alam yang unreplaceable.

2) Safeguarding atau pengamanan terhadap kelestarian sumber daya alam dan lingkungan hidup yang ada dan pencegahan terjadi gangguan ekosistem dalam rangka menjamin kualitas kehidupan yang tetap baik bagi generasi yang akan datang.

3) Pemanfaatan dan pengelolaan sumberdaya alam semata untuk kepentingan mengejar pertumbuhan ekonomi demi kepentingan pemerataan pemanfaatan sumberdaya alam yang berkelanjutan antar generasi.

${ }^{20}$ Sutamihardja, Perubahan Lingkungan Global; Program Studi Pengelolaan Sumber Daya Alam dan Lingkungan Sekolah Pascasarjana; IPB, Bogor, 2004, hlm. 57 
4) Mempertahankan kesejahteraan rakyat (masyarakat) yang berkelanjutan baik masa kini maupun masa yang mendatang (inter temporal).

5) Mempertahankan manfaat pembangunan ataupun pengelolaan sumberdaya alam dan lingkungan yang mempunyai dampak manfaat jangka panjang ataupun lestari antar generasi.

6) Menjaga mutu ataupun kualitas kehidupan manusia antar generasi sesuai dengan habitatnya.

Sebagai kesimpulan tentang bagaimana pembangunan berkelanjutan pada pertambangan batubara, dimana setiap stakeholder harus melihat pertambangan batubara secara holistik yang menyatukan pembangunan baik itu ekonomi, sosial dan lingkungan hidup. Dimensi ini dijalankan dengan dimensi jangka waktu yang panjang atau lintas generasi, prinsip efisiensi total dan diarahkan pada pemberantasan kemiskinan (ekonomi), ekuiti sosial dan kualitas lingkungan hidup yang lebih tinggi ${ }^{21}$ (lihat Gambar 5). Oleh karena itu dengan metode pembangunan berkelanjutan ini, upaya peningkatan kesejahteraan rakyat dapat terjadi karena prinsip keseimbangan pada 3 prinsip pokok di atas.

Gambar 5. Three Pillar Basic Model, dimensi pembangunan berkelanjutan (Sustainable Development), dibahas dalam KTT Rio, bahwa pembangunan yang memenuhi generasi sekarang tanpa mengurangi kemampuan generasi yang akan datang dalam memenuhi kebutuhannya

Dimension of Sustainability

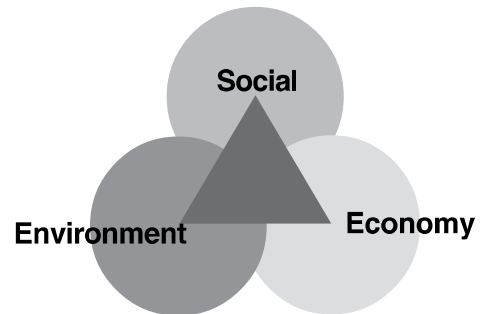

Sumber: Aparna Susarla, Sustainable Development: An Introduction, Centre for Environment Education, Volume I, 2007.

\section{Metode Pengelolaan Pertambangan Batubara Berdasarkan UUD 1945}

Seperti telah dijelaskan diawal, bahwa pengusaan asing pada pertambangan batubara sangat dominan, apalagi batubara diekspor keluar negeri mengakibatkan pasokan dalam negeri menjadi berkurang. Solusinya adalah pemerintah harus menekan jumlah ekspor batubara Indonesia tersebut dan mengalihkan

21 Man S Sastrawidjaja, (eds.), Padamu Negeri, Mewujudkan Sistem Hukum yang Adil dan Beradab bagi Pembangunan Nasional yang Berkelanjutan, Unpad Press,Bandung, 2004, hlm. 42-43. 
kepemenuhan domestik. Agar batubara tetap bisa dinikmati oleh masyarakat Indonesia pada generasi mendatang. Cara yang bisa digunakan untuk itu adalah dengan menggunakan prinsip pembangunan berkelanjutan.

Sudah saatnya Indonesia kembali pada sistem ekonomi Indonesia yaitu sistem ekonomi kerakyatan, sebagaimana dikemukakan dalam Pasal 33 UUD 1945, adalah sebuah sistem perekonomian yang ditujukan untuk mewujudkan kedaulatan rakyat dalam bidang ekonomi. Empat prinsip dasar ekonomi kerakyatan adalah sebagai berikut: 1) perekonomian disusun sebagai usaha bersama berdasar atas azas kekeluargaan; 2) cabang- cabang produksi yang penting bagi negara dan yang menguasai hajat hidup orang banyak dikuasai oleb negara, dan; 3) bumi, air, dan segala kekayaan yang terkandung didalamnya dikuasai oleh negara dan dipergunakan sebesar-besarnya bagi kemakmuran rakyat. 4) Perekonomian nasional diselenggarakan berdasar atas demokrasi ekonomi dengan prinsip kebersamaan, efisiensi berkeadilan, berkelanjutan, berwawasan lingkungan, kemandirian, serta dengan menjaga keseimbangan kemajuan dan kesatuan ekonomi nasional.

Berdasarkan keempat prinsip tersebut dapat dilihat betapa sangat besarnya peran negara dalam sistem ekonomi kerakyatan. Sebagaimana dilengkapi oleh Pasal 27 ayat (2) dan Pasal 34, peran negara dalam sistem ekonomi kerakyatan antara lain meliputi 5 hal sebagai berikut: 1) mengembangkan BUMN; 2) memastikan pemanfaatan bumi, air, dan segala kekayaan yang terkandung didalamnya sebesar-besarnya bagi kemakmuran rakyat; 3) memenuhi hak setiap warga negara untuk mendapatkan pekerjaan dan penghidupan yang layak, dan; 4) memelihara fakir miskin dan anak terlantar. Peranan hukum sudah seharusnya mengiringi dan mengawal sistem ekonomi kerakyatan sebagaimana dimaksud dalam UUD 1945 tersebut di atas.

Dalam rangka memperbaiki kembali ekonomi kerakyatan, adalah kewajiban setiap elemen bangsa untuk memastikan bahwa pemimpin Negara bukanlah pemimpin yang secara jelas mengimani dan mengamalkan neoliberalisme. Dukungan yang lebih besar sekaligus kritik dan kontrol harus diberikan kepada 
pemimpin yang secara jelas dan tegas mengungkapkan komitmen mereka untuk menyelenggarakan sistem ekonomi kerakyatan di Indonesia.

\section{Metode Ekonomi Kemerataan sebagai Telaah Perbandingan}

Ekonomi kemerataan adalah melaksanakan suatu sistem ekonomi sebagaimana diperintahkan Allah SWT, atau yang biasa disebut "Ekonomi Islam". ${ }^{22}$ Nabi Muhammad SAW melaksanakan Ekonomi Kemerataan itu, di negara Madinah. Dengan beberapa landasannya adalah: 1) Mandiri, tidak boleh nebeng; 2) Achievement oriented; 3) Persaudaraan atau harmoni, dan kekuatan; 4) dan "transfer of wealth" dari si kaya (muzakki) kepada si miskin (mustahik), berupa Zakat, Infak, dan Sodakoh. ${ }^{23}$

Daya dorongnya adalah ibadah kepada Allah SWT, atau menyerahnya -selfinterest" kepada "God's interest", atau Kehendak Allah. Ada pun rangkaian yang timbul dari padanya menimbulkan sistem ekonomi yang Hanif, yang bukan "competition for gain" (=perolehan), akan tetapi "competition for achievement" (=prestasi) atau di dalam Al-Qur'an disebut "fastabiqu al khairati"24 (dalam AlQuran, 2 : 148) yang artinya:

Dan bagi tiap-tiap umat ada kiblatnya (sendiri) yang ia menghadap kepadanya. Maka berlomba-lombalah kamu (dalam berbuat) kebaikan. Di mana saja kamu berada pasti Allah akan mengumpulkan kamu sekalian (pada hari kiamat). Sesungguhnya Allah Maha Kuasa atas segala sesuatu.

Ini menimbulkan suatu sistem ekonomi yang bersifat merata, seperti diperintahkan oleh Surah An-Nahl ayat 71,yang artinya:

"dan Allah melebihkan sebagiankamu dari sebagian yang lain dalam hal rezeki......agar mereka sama (merasakan) rezeki itu....."

Perintah ini, dalam terminologi yang berlaku sekarang, disebut Ketimpangan Ringan, dengan Rasio Gini sebesar 0,1-0,3. Maka, perekonomian yang harus kita jalankan adalah perekonomian dengan ketimpangan ringan itu. Inilah tujuan untuk dicapai. ${ }^{25}$

${ }^{22}$ Herman Soewardi, Roda Berputar Dunia Bergulir, Kognisi Baru tentang Timbul - Tenggelamnya Sivilisasi, Bakti Mandiri, Bandung, 2004, hlm. 86.

${ }^{23}$ Ibid., hlm. 89.

${ }^{24}$ Ibid.

${ }^{25}$ Ibid. 
Mekanisme ini adalah perpaduan antara perintah melakukan ZIS dan larangan untuk memungut riba. Argumentasinya adalah sebagai berikut:

ZIS adalah "transfer of wealth" dari si kaya (muzakki) kepada si miskin (mustahik). Bila hanya salah satu sajayang dijalankan maka ketimpangan ringan itu tak kan tercapai. Bila ZIS dilaksanakan dan riba tetap dipungut, maka akan tercapai penyedotan kembali kepada si kaya (yang memiliki kapital). ${ }^{26}$

Dasarnya adalah Q.S Al-Baqarah: 276 yang artinya “Allah memusnahkan riba dan menyuburkan sodakoh ...". Oleh karena itu, kesatu-paduan dari perintah melakukan ZIS dan larangan memungut riba itu memiliki "hubungan fungsional", yang satu menguatkan yang lain, agar tujuan, ialah Ketimpangan Ringan, tercapai.

Capaian Ekonomi Kemerataan adalah "rapid growth" sebagaimana telah diteladankan oleh Nabi Muhammad SAW di Madinah. Dengan memproduktifkan para dhuafa (kaum lemah), semua orang berpartisipasi di bidang ekonomi, maka pertumbuhan pun tercapai dengan cepat. ${ }^{27}$

Ekonomi kemerataan adalah ekonomi "need fulfilment" (yang ada ukurannya), bukan ekonomi "want fulfilment", yang tidak pernah puas itu ("variety is the spice of life"). Dalam rangka need fulfilment ini, tetap akan terjadi akumulasi kapital, namun kemungkinannya kecil. Tapi, bila pemodal-pemodal kecil itu bergabung, terjadilah akumulasi kapital yang besar. Inilah prinsip koperasi. Yang harus dipertahankan adalah tetap pada ketimpangan ringan dengan Rasio Gini 0,1 - 0,3, atau perbandingan antara $10 \%$ penduduk termiskin dan $10 \%$ penduduk terkaya adalah 1:9.28

Dalam perbandingan tersebut di atas, dapat ditarik titik temu yang sama dengan Indonesia, yaitu koperasi yang sesuai dengan Pasal 33 UUD 1945. Bank di Indonesia juga sudah banyak yang berprinsipkan syariah, sehingga dasar-dasar Islam juga sudah diterapkan.

\section{Kajian Aksiologi: Nilai Kegunaan Ilmu}

Aksiologi menurut Jujun, sebagai teori nilai yang berkaitan dengan kegunaan dari pengetahuan yang diperoleh ${ }^{29}$ Kegunaan kajian filsafat ilmu terhadap

${ }^{26}$ Ibid.., hlm. 90.

${ }^{27} \mathrm{Al}$ Assad dan A. Karim, Sistem Ekonomi Islam, Prinsip-prinsip dan Tujuannya, PT. Alharamain, Singapura, 1981, hlm.100. Dalam Herman Soewardi, Ibid.

${ }^{28}$ Herman Soewardi, Ibid.

${ }^{29}$ Jujun S Suriarumantri, Loc. Cit. 
pemanfaatan sumber daya alam pertambangan batubara sebagai upaya meningkatkan kesejahteraan rakyat Indonesia adalah menelaah manfaat positif dan negatif agar kesejahteraan rakyat semakin meningkat. Karena dampak negatif itu tidak bisa dihindari, tetapi paling tidak bisa dicarikan solusi dan meminimalisir masalah yang ada.

Irwandy Arif mengemukakan manfaat ekonomi kegiatan pertambangan. Manfaat ekonomi kegiatan pertambangan dibagi menjadi dua manfaat, yaitu: 1) Manfaat langsung; 2) Manfaat tidak langsung. ${ }^{30}$

Manfaat langsung merupakan faedah atau kegunaan yang terus dirasakan, baik oleh pemerintah, pemerintah daerah maupun masyarakat akibat adanya kegiatan pertambangan batubara. Manfaat langsung itu meliputi: a. Penerimaan pajak dan royalti. Kontribusi pajak dan royalti bagi pemerintah pusat dan daerah, menjadi sumber dan pembangunan untuk kesejahteraan masyarakat; b. Penciptaan lapangan kerja. Rekrutmen masyarakat lokal dan daerah akan meningkatkan pendapatan perkapita, kualitas hidup, serta keterampilan masyarakat; c. Bahan tambang untuk industri pengolahan.Tambang yang dihasilkan dalam bentuk ore, menjadi bahan mentah yang bisa digunakan oleh industri-industri pengolahan hingga menjadi final good.

Manfaat tidak langsung merupakan manfaat tidak dinikmati secara langsung oleh masyarakat, namun masyarakat dapat menikmati dan merasakan akibat adanya kegiatan pertambangan batubara. Manfaat tidak langsung dari kegiatan pertambangan batubara adalah: a. Sirkulasi barang dan jasa. Belanja kebutuhan operasi karyawan akan menjadi penggerak ekonomi masyarakat lokal, regional dan nasional; b. Pembangunan infrastruktur. Keberadaan kegaitan tambang akan diikuti dengan pembangunan infrastruktur, seperti jalan, pelabuhan, dan infrastruktur lain, rumah sakit, sekolah, sarana ibadah dan lainnya. Keberadaan infrastruktur akan dinikmati oleh masyarakat yang berada di lingkar tambang maupun di luar wilayah pertambangan; c. Munculnya usaha pendukung.Lokasi tambang akan melahirkan usaha pendukung untuk memasok kebutuhan pangan, sandang, dan papan karyawan; d. Industri pengolahan tambang. Keberadaan tambang akan melahirkan

${ }^{30}$ Irwandy Arif, "Peran Industri Pertambangan Saat ini terhadap Pembangunan Nasional dan Daerah", disampaikan pada Seminar Pertambangan di Universitas Mubammadiyah Mataram, tanggal 21 Maret 2009, hlm. 35. 
industri pengolahan hasil tambang, yang juga memiliki manfaat langsung dan tidak langsung, dan rantai nilai tambah yang sangat panjang dan dapat menciptakan lapangan pekerjaan, produk-produk turunan dan sebagainya. ${ }^{31}$

Sementara itu dampak negatif perusahaan tambang batubara, meliputi: ${ }^{32}$ 1) Timbulnya konflik atau sengketa antara masyarakat dengan perusahaan tambang dan antara pemerintah daerah dengan pemerintah pusat akibat adanya divestasi saham dari pemodal asing; 2) Menurunnya moral masyarakat; 3) Pelanggaran HAM; 4) Melonjaknya harga bahan kebutuhan sehari-hari, seperti harga ikan dan daging yang cukup mahal; 5) Rusaknya lingkungan fisik, dan lain-lain.

Dengan menggunakan epistimologi di atas, peningkatan kesejahteraan rakyat dapat dicapai lebih baik lagi, manfaat yang didapat diantaranya:

1) Pengelolaan pertambangan batubara dikelola oleh Indonesia sendiri secara mandiri, bisa dengan meningkatkan peran BUMN dan pengembangan Koperasi.

2) Pengalihan pada pemanfaatan domestik dan bisa dimanfaatkan untuk jangka waktu yang lebih lama.

3) Keuntungan industri pertambangan lebih besar untuk kembali pada kemanfaatan rakyat.

4) Lingkungan bisa lebih baik karena tanggungjawab kepada negara sendiri.

5) Tenaga kerja Indonesia bisa lebih banyak lagi, peningkatan skill pada pengembangan tenaga kerja bisa maksimal sebagai regenerasi sumberdaya manusia.

6) Konflik dengan masyarakat tidak ada lagi jika masyarakat sekitar diberikan peran dalam pengelolaan tambang batubara.

7) Ketimpangan kesejahteraan lebih kecil porsinya karena dengan menjalankan ekonomi kemerataan, prinsip sedekah adalah melindungi masyarakat ekonomi lemah, dan lain sebagainya.

\section{Penutup}

Berdasarkan pada uraian pembahasan, dapat ditarik kesimpulan, yaitu pertama, dalam kajian ontologi bahwa pertambangan batubara memberikan konstribusi terhadap perekonomian nasional yang harusnya dijalankan secara selaras sesuai Pasal 33 ayat (3) dan (4) UUD 1945. Refleksi saat ini adalah penguasaan oleh negara lebih mendominasi pemanfaatannya, sehingga perlu penyeimbang baru berupa kebijakan pengelolaan nasional. Kedua, pada kajian epistimologi, perlu menggunakan prinsip

\footnotetext{
${ }^{31}$ Ibid.

32 Salim, Ibid., hlm. 73.
} 
pembangunan berkelanjutan, yaitu keberlanjutan ekonomi, sosial, dan lingkungan, merupakan langkah yang tepat untuk meningkatkan kesejahteraan rakyat dalam pertambangan batubara dengan sistem ekonomi kerakyatan berdasarkan pada Pasal 27 ayat (2), Pasal 33 dan Pasal 34 UUD 1945 dan sistem ekonomi pemerataan sebagai telaah perbandingan yang juga sesuai dengan koperasi di Indonesia. Ketiga, pada kajian aksiologi diperlukan adanya pemanfaatan langsung dan tidak langsung untuk meningkatkan kesejahteraan rakyat Indonesia.

\section{Daftar Pustaka}

\section{Buku}

Arif, Irwandi, Batubara Indonesia, PT. Gramedia Pustaka, Jakarta, 2014.

Assad, Al dan Karim A, Sistem Ekonomi Islam, Prinsip-Prinsip dan Tujuannya, , PT. Alharamain, Singapura, 1981.

Badan Geologi, Batubara di Indonesia, 2011.

Bakhtiar, Amsal, Filsafat Ilmu, PT RajaGrafindo Persada, Jakarta, 2005.

Direktorat Mineral dan Batubara Kementrian Energi dan Sumber Daya Mineral, 2013.

Fauzi, Akhmad,Ekonomi Sumber Daya Alam dan Lingkungan, Teori dan Aplikasi, PT. Gramedia Pustaka Utama, Jakarta, 2013.

Kebijakan Energi Nasional-Direktorat Jenderal Listrik dan Pemanfaatan Energi (KEN-DJLPE), 2014.

Negoro, Darsono prawiro, Filsafat Ilmu, Kajian tentang Pengetahuan yang Disusun secara Sistematis dan Sistemik dalam Membangun Ilmu Pengetahuan, Nusantara Consulting, Jakarta, 2011.

Salim, Hukum Pertambangan Mineral dan Batubara, Sinar grafika, Jakarta, 2014.

Sastrawidjaja, Man S. (eds.), Padamu Negeri, Mewujudkan system hukum yang adil dan beradab bagi pembangunan nasional yang berkelanjutan, Unpad Press, Bandung, 2004.

Soewardi, Herman, Roda Berputar Dunia Bergulir, Kognisi Baru tentang Timbul tenggelamnya Sivilisasi, Bakti Mandiri, Bandung,2004.

Suriarumantri, Jujun S, Filsafat Ilmu Sebuah Pengantar Popular, Pustaka sinar harapan, Jakarta, 2013.

Sutamihardja, Perubahan Lingkungan Global; Program Studi Pengelolaan Sumber Daya Alam dan Lingkungan Sekolah Pascasarjana; IPB, Bogor, 2004,

Tim Dosen Filsafat Ilmu Fakultas Filsafat UGM, Filsafat Ilmu sebagai Dasar Pengembangan Ilmu Pengetahuan, Liberty, Yogyakarta, 2001.

Wood Machencie, Coal Supply Services, ANZ, 2011. 


\section{Jurnal}

Nahib, Imadi, "Pengelolaan Sumberdaya tidak Pulih Berbasis Ekonomi Sumberdaya (Studi Kasus: tambang Minyal Blok Cepu), Jurnal Ilmiah Geomatifka, Vol. 12 No. 1 Agustus 2006.

Prayogo, Dody, "Corporate Social Responsibility, Social Justice dan Distributive welfare dalam Industri tambang dan migas di Indonesia,"Jurnal Galang, Volume 3 No. 3 Desember 2008.

Susarla, Aparna, "Sustainable Development: An Introduction,"Jurnal Centre for Environment Education, Volume I, 2007.

\section{Makalah}

Arif, Irwandy, "Peran Industri Pertambangan Saat ini terhadap Pembangunan Nasional dan Daerah", disampaikan pada Seminar Pertambangan di Universitas Muhammadiyah Mataram, tanggal 21 Maret 2009.

\section{Peraturan Perundang-undangan}

Undang-Undang Dasar Negara Republik Indonesia Tahun 1945.

Undang-Undang No. 4 Tahun 2009 tentang Pertambangan Mineral dan Batubara (Lembaran Negara Republik Indonesia Tahun 2009 Nomor 4, Tambahan Lembaran Negara Republik Indonesia Nomor 4959).

Keputusan Menteri No. 1991 K/30/MEM/ 2011 tentang Penetapan Kebutuhan dan

Persentase Minimal Penjualan Batubara untuk Kepentingan Dalam Negeri Tahun 2012.

\section{Internet}

http:/ / bisnis.news.viva.co.id/news/read/178888-negara-terkaya---termiskin-dimana-indonesia-, diakses 15 Desember 2015.

http://www.indonesia.go.id/in/potensi-daerah/sumber-daya-alam, diakses 15 Desember 2015.

http:/ / www.metrosiantar.com/2013/08/01/73888/mayoritas-sumber-energidikuasai-asing/, diakses 15 Desember 2015.

https:/ / sites.google.com/site/saefullahwiradipradja/lecture-materials, Wiradipradja, E. Saefullah, Materi Filsafat Ilmu (Revisi) Program Studi Doktor Pascasarjana Unpad, diakses 31 September 2015.

Kates, Robert W, et. al., Enviroment: Science and Policy for Sustainable Development, www.heldref.org/env.php, Volume 47, number 3 Page 8-21, 2005. 